\title{
Zines as Reflective Evaluation Within Interdisciplinary Learning Programmes
}

\author{
Autumn Brown ${ }^{1,2 *}$, Mairéad Hurley ${ }^{2}$, Sophie Perry ${ }^{1}$ and Joseph Roche ${ }^{1,2}$ \\ ${ }^{1}$ Science Gallery at Trinity College Dublin, Dublin, Ireland, ${ }^{2}$ School of Education, Trinity College Dublin, Dublin, Ireland
}

\section{OPEN ACCESS}

Edited by: Marianne Lykke,

Aalborg University, Denmark

Reviewed by: Kristina Maria Madsen, Aalborg University, Denmark Allen Leung, Hong Kong Baptist University, China Rasmus Grøn, Aalborg University, Denmark

*Correspondence: Autumn Brown browna3@tcd.ie

Specialty section: This article was submitted to STEM Education, a section of the journal Frontiers in Education

Received: 02 March 2021 Accepted: 18 May 2021 Published: 09 June 2021

Citation:

Brown A, Hurley M, Perry $S$ and Roche J (2021) Zines as Reflective Evaluation Within Interdisciplinary Learning Programmes. Front. Educ. 6:675329. doi: 10.3389/feduc.2021.675329
This paper presents a unique method for documenting and reflecting learning in interdisciplinary science learning settings, which prioritises the perspectives of marginalised learners and which may be used across cultural contexts. Short for "magazine" or "fanzine," zines are small DIY booklets which can contain poetry, narrative, drawings, comics, collage and more. Often associated with radical or alternative cultures, they can become a kind of self-made soapbox for the creator, a material artifact that, by its very deconstructed and deconstructing nature, encourages a personalised remixing of ideas. Within this paper, we examine the practical and pedagogical positioning of zines within a STEAM (Science, Technology, Engineering, Arts, and Mathematics) context. As both a visual and text-based artifact, a zine is uniquely capable of capturing broad responses to diverse learning experiences which blur disciplinary boundaries and offers an inclusive and firmly emancipatory approach to reflective practice.

Keywords: informal science learning, STEAM (enriched with arts), equity, reflection, social justice, evaluation, widening participation

\section{INTRODUCTION}

Science learning that takes place in out-of-school settings has been an active area of research for several decades (Falk and Dierking, 2000; Braund and Reiss, 2004). In recent years there has been a renewed focus on how science learning in these settings may have a greater impact on lifelong learning by strengthening partnerships between formal and informal educators, supporting social learning, and providing greater freedom for people to choose how and when they engage with science (Dunlop et al., 2019). Different pathways for learners, or learning ecologies, can cover a wide range of learning environments but often focus on children and school-related programmes rather than higher education and adult learning (Sangrá et al., 2019). The need for broader considerations of science learning is reflected in the growing number of conceptualisations across the field, which often highlight participatory approaches such as citizen science, co-creation, and inclusive science communication (Durall et al., 2020; Polk and Diver, 2020; Roche et al., 2020).

A key focus in the development of participatory theoretical frameworks for informal science learning is giving appropriate consideration to the role of location and community, especially for marginalised youth who face systemic barriers to inclusion (Dawson, 2018; Nazar et al., 2019). Informal science learning programmes have traditionally focused on how these groups can be better supported to improve their access to science education outside of the classroom (Calabrese Barton and Tan, 2018). Rather than aiming to change how young people engage with science in out-of-school settings, it is becoming increasingly clear that it is the field of 
informal science learning which must change in order to support more equitable participation (Archer et al., 2021).

Learning environments must find common ground between scientific knowledge and cultural knowledge (Gondwe and Longnecker, 2015). This will improve how western science interacts with sociocultural learning and indigenous ways of knowing and being (Tzou et al., 2019). Such cross-cultural conceptualisations of how learners engage and communicate science are important for dismantling infrastructures of exclusion (Orthia, 2020). This is especially pertinent for the most vulnerable groups in society, such as migrants and refugee populations. In addition, the responsibility for more equitable and inclusive practice extends not only to museums, science centers, zoos, and aquariums, but to all informal science learning spaces (Brown et al., 2020). Along with inclusive environments, more robust and reliable research methods are needed to evaluate and assess science learning in out-of-school settings, especially those evaluation approaches which are responsive to the lived experiences and voices of nondominant communities (Garibay and Teasdale, 2019).

This paper describes one such method, a unique approach to reflective evaluation, which prioritises the perspectives of marginalised learners and may be used across cultural contexts in informal and out-of-school settings.

It addresses the research question: How might reflective learning be facilitated and documented across interdisciplinary settings and cross-cultural contexts?

This approach uses zines-handmade booklets which may contain poetry, comics, collage, drawings, and more. Zines offer a highly creative and personalised way to explore, critique and reflect upon a given topic through multiple means (Radway, 2001). Here, the historical evolution of zines and their development as a creative and informal way to carry out reflective evaluation is introduced. Zines are then examined within the context of a STEAM-orientated pedagogical framework and a method of engaging young people in multiple interdisciplinary science learning environments. The paper shares a number of examples from the development period of the tool as a medium of reflection and concludes with recommendations on how this approach can be implemented by researchers and practitioners in the STEAM learning field and beyond. We suggest that the method presented in this paper is flexible enough to be adapted for use in other out-of-school learning programmes and contexts, such as science centers or natural history museums, cultural heritage or the arts.

\section{Radical Roots: A Brief History of Zines}

While small circulation ephemera such as political pamphlets, leaflets, and flyers have a long and varied history, there were a number of critical moments which defined the zine format and movement. In November 1926, a group of individuals solicited contributions for a unique, non-commercial publication, FIRE!! This small circulation periodical included artwork, poetry, and essays from great thinkers and revolutionaries of the Harlem Renaissance (FIRE!! 1926). It chronicled and celebrated black excellence and explored subjects such as queerness, and femininity, subjects which mainstream publications often refused to cover. Financed by its creators, including celebrated authors Langston Hughes, Zora Neale Hurston, Aaron Douglas, Richard Bruce Nugent, and Wallace Thurman, the independent publication allowed young black artists to represent their values, ideas and experiences (Johnson and Johnson, 1974). Although short lived, the publication created a lasting impact. While the youth of the Harlem Renaissance were excited by the radical perspectives on queer romance and political criticism, other readers were appalled. In the excitement following this fierce debate, other "non-commercial non-professional small circulation publications" known as zines appeared Duncombe, (1997), including Harlem and Black Opals (Johnson and Johnson, 1974).

In the 1930s and 1940s, science fiction fan clubs such as the Science Fiction League (SFL) further popularised the zine medium (Bretnor, 1974). SFL members came together to discuss and rework stories in their own periodicals published within their community. They became a tool for women in particular to critique and reimagine popular stories from a feminine point of view, or to feature leading female characters (Radway, 2011; Vong, 2016).

Zines experienced another wave of popularity in the late 1960s and throughout the 1970s, playing a critical role in the dissemination of anti-establishment and feminist ideology in the United States and the United Kingdom (Garrison, 2000; Chidgey, 2009). As Punk and D.I.Y scenes emerged, and the rise of copy shops provided greater distribution powers to zine creators, publications such as Sniffin' Glue and Profane Existence leapt from the counterculture movement and into the mainstream (Duncombe, 1997; Bartel, 2004). In each historical iteration, zines provided an intellectual space outside of the mainstream. Where creators did not see themselves, their experiences, values or identities represented, zines provided a new kind of public sphere where communities could be found or created with little more than paper, ink, and a few old magazines. (Bleyer, 2004; Guzzetti and Gamboa 2004).

\section{Contemporary Zine Culture in Education}

More recently, zines have seen a resurgence in popularity both online and in paper form. These roots in civic engagement, critical analysis and personalisation have produced a powerful reflective tool which allows learners to represent themselves and construct meaning through multiple visual and textual means (Guzzetti and Gamboa, 2004; Poletti, 2005). As zine creators, the medium positions learners not as consumers of knowledge, but as critics, creators, and crucially, experts in their own communities of knowledge (Yang, 2010; Desyllas and Sinclair, 2014). With pen and paper, anyone can become a zinester (someone who makes zines). This material accessibility makes zines an ideal tool for learning contexts where technological resources are limited (Guzetti, 2009; Guzzetti and Gamboa, 2004; Knobel and Lankshear, 2002).

Researchers Rallin and Barnard (2008) brought zines into formal learning spaces, including university courses on literary analysis and composition. Here they used zines to encourage students to "to interrogate how knowledge serves specific 


\begin{tabular}{|c|c|c|}
\hline EXPLORING & MEANING-MAKING & CRITIQUING \\
\hline Noticing \& questioning & Producing representations & Hacking the ideas of others \\
\hline Exploring materiality & Engaging multiple modalities & Cultivating dissent \\
\hline Defining the problem space & Finding relevance & $\begin{array}{c}\text { Holding commitments to the stand- } \\
\text { ards of the field }\end{array}$ \\
\cline { 2 - 3 } & & \begin{tabular}{c} 
Sharing results \& audiencing \\
\cline { 2 - 3 }
\end{tabular} \\
& & \\
\hline
\end{tabular}

FIGURE 1 | Framework for using zines as a STEAM learning and reflective tool. Adapted from (Mejias et al., 2021).

political, and social interests, to cultivate a questioning relationship to their own knowledge and to dominant modes of knowledge dissemination" (Rallin and Barnard, 2008). DeGravelles (2011) found that zine pedagogy has been used across formal and informal learning settings as a way to empower students through accessibility, self-authorisation, and participation.

A number of science communicators and educators have also experimented with this medium (Dunwoody, 1992; Yang, 2010; ScienceGrrl, 2018; Liu, 2019) encouraged his biology students to go beyond consuming scientific knowledge, by creating zines which invited critical responses and reimaginings of scientific concepts and phenomena. This kind of participatory literacy encourages learners to take possession of knowledge and find new ways to explore, explain and apply these ideas. "In a world where scientific knowledge is increasingly complex and technical, the participatory literacy of zines can foster a sense of ownership that is often lacking for those who don't have the chance to study science formally or at an advanced level, or who had a bad experience with science learning in their educational past" (Yang, 2010).

\section{PEDAGOGY}

\section{Zines as a Science, Technology, Engineering, Arts, and Mathematics Pedagogy}

STEAM (Science, Technology, Engineering, Arts, and Mathematics) is a term used to describe a growing field of research and practice that includes the arts among the more commonly combined STEM subjects (Liao, 2016). A number of recent studies have highlighted the transformative learning potential of informal STEAM programmes (Costantino, 2018; Lee and Soep, 2018; Bevan et al., 2020a). The creative inquiry model of STEAM learning presented by Costantino (2018) builds on the problem-based, inquiry-based, and hands-on learning features of STEM education, alongside the arts and design "signature pedagogy" which features the key areas of critical making and object-based learning, critique, and exhibition. This creative inquiry model "demonstrates a mutually engaged transdisciplinary approach for STEAM learning” (Costantino, 2018 , p.6). In their thorough overview of the various contested conceptualisations of the term STEAM, Mejias et al. (2021), (p.209) also feature the word "mutual", concluding that STEAM has the most potential for positive impact when the arts is given equal status among the STEM subjects, and both are "mutually instrumental" to one another. Bevan et al. (2019) and Mejias et al. (2021) present a framework of conjectured STEAM epistemic practices developed through observation of out-ofschool transdisciplinary art and science programmes for youth, including those in Science Gallery Dublin described in Learning Environments and Methods. We adopt a version of this framework, modified by us, as a pedagogical model within which to position zines as a STEAM learning and reflective tool (Figure 1).

The zine-making sessions outlined in the subsequent sections of this paper asked students to reflect on their learning within an informal STEAM environment and are designed to surface these epistemic practices of STEAM in their own right, as described in the following questions that a zine-maker may ask themselves during one such session. These questions were developed specifically for the zine activity and highlight the adaptability and flexibility of the STEAM pedagogy framework of Mejias et al. (2021). This provides an example of how practitioners may examine the STEAM potential of their proposed activities under the three strands of this framework: exploring, meaning-making and critiquing.

\section{Exploring}

1. Noticing and questioning-what and when did I learn? Who did I learn from/with? How did I learn?

2. Exploring materiality-what materials shall I use to create my zine? Can I improve and personalise my zine by adding different materials? 
3. Defining the problem space-which element of my learning shall I focus on in this tiny booklet? What feels personally important enough to capture? How much detail can I go into?

\section{Meaning-Making}

1. Producing representations-how do I convey my message? Can I represent feelings and emotions visually, in text or using materials?

2. Engaging multiple modalities-Can I use text, visual art, digital media, even tactile or embodied representations to embellish or accompany my zine?

3. Finding relevance-can I show the relevance of the topic or the learning experience to my own life, my identity? What are the broader social, cultural, political implications of the topic that affect me, my social group, my family, my country?

\section{Critiquing}

1. Hacking the ideas of others-can I remix or repurpose the ideas I have encountered, and combine conjecture and hypothesis to create personal relevance and meaning? Can I use the tools I have at my disposal to be creative?

2. Cultivating dissent-what is my own personal reaction to these ideas? What is the implication of my learning experience? Do I have critical agency?

3. Holding commitments to the standards of the field-what is a zine? Who has used them in the past and why? Does my zine share the features and form? Am I a "zinester?"

4 Sharing results and "audiencing"-am I ready to share my personal creation with the world?

\section{Zines as Reflective Tools in Informal Learning Spaces}

Rather than simply offering an opportunity for learners to recall or recite educational experiences, when paired with effective prompts or provocations, zines encourage their creators to reflect deeply on the implications of their learning experiences and to situate them in their own contexts. Reflection can be understood as an active cognitive process in which a learner deliberately contemplates an experience (Dewey, 1933). This process provides opportunities for learners to seek and find connections between previous knowledge and experiences (Di Stefano et al., 2017).

As a result of the level of engagement from learners that reflection requires, it is used as a key practice within education research across formal, non-formal, and informal learning environments (Williamson, 1994; Congdon and Blandy, 2005; Yang, 2010; Moore et al., 2020). Though reflection can be difficult to capture, learner-made zines offer a rich insight into learners' personal learning processes. Together with prompts, zines offer a structured form of reflective support and as such are more likely to be accessible for many participants (Carlile and Jordan, 2007). Researcher and educator ToddHonma, (2016) (p.33) has noted, "Because of their do-it-yourself ethos, zines are often embraced by those from marginalized backgrounds because of their freedom to experiment with different modes of writing, expression, and presentation." While other mediums such as annotated portfolios Löwgren, (2013); Hall, (2020), user stories Cohn, (2004); Matuk et al. (2016), autoethnographies Tutkal et al. (2021); Souto-Manning, 2010) also support learner-led reflection, zines offer learners a sense of subversion and ownership that other more institutionalised forms of writing do not provide (Lonsdale, 2015). Zine-making encourages multimodal composition, transdisciplinary exploration, and participatory culture in creating pieces of work which are meant to draw attention to what is meaningful and impactful to their creators (DeGravelles, 2011; Lonsdale, 2015).

In order to explore the levels of reflection which emerge during the zine-making process, this approach adopts the Ryan and Ryan (2015) 4R Reflection Scale: reporting/responding, relating, reasoning, and reconstructing. Reflection may be represented in many forms and a straightforward categorisation was proposed by Ryan and Ryan (2015) to help researchers fathom the depths of reflection encouraged or discouraged by a medium. Figure 2 demonstrates how the text in zines (column 1) might correlate to the different depths of reflection described by Ryan and Ryan (2015) (column 3).

\section{LEARNING ENVIRONMENTS}

This paper shares the experience of developing and using zines within inter-or transdisciplinary learning programmes hosted by Science Gallery at Trinity College Dublin (Ireland) ${ }^{1}$, Ars Electronica (Austria) ${ }^{2}$, Waag (Netherlands) ${ }^{3}$, Kersnikova Institute (Slovenia) ${ }^{4}$, and LATRA (Greece) ${ }^{5}$. These institutions offer learning experiences that are situated beyond the formal classroom environment, and as such offer free-choice (Dierking, 2005; Falk, 2005), or informal (Bell et al., 2009) learning opportunities. Together, they serve learners from an array of backgrounds with diverse educational experiences, aged between 11 and 21. For example, LATRA serves young people who are refugees or migrants; their zine workshops specifically engaged learners aged 16-18, two of whom were unable to read and write as they had never attended school. Science Gallery Dublin's STEAM workshop series serves young people in full-time education, aged 15-17, who are taking one week out of school to attend these STEAM workshops, while Waag's program is a weekend school for disadvantaged children in Amsterdam aged 9-14. At the Kersnikova Institute, learners aged 10-14 participated in a weeklong series of programming and robotics workshops. The unifying factor between these locations is a pedagogical approach which combines one or more STEM subjects with the arts, and meeting the criteria set out by Mejias et al. (2021) of being mutually instrumental and

\footnotetext{
${ }^{1}$ https://dublin.sciencegallery.com/

${ }^{2} \mathrm{https} / / /$ ars.electronica.art/news/en/

${ }^{3}$ https://waag.org/en/home

${ }^{4}$ https://kersnikova.org/en

${ }^{5}$ https://latra.gr/
} 


\begin{tabular}{|c|c|c|}
\hline $\begin{array}{c}\text { WHAT YOU MIGHT SEE } \\
\text { (in a learner's zine) }\end{array}$ & WHAT THIS EXEMPLIFIES & $\begin{array}{c}\text { WHAT THIS MEANS } \\
\text { (depth of reflection) }\end{array}$ \\
\hline $\begin{array}{c}\text { "Today we did a drama work- } \\
\text { shop about space" }\end{array}$ & $\begin{array}{c}\text { Describing an incident or } \\
\text { experience }\end{array}$ & Reporting / Responding \\
"I learned how to..." & $\begin{array}{c}\text { Relating } \\
\begin{array}{c}\text { choices I have made about } \\
\text { buying food and clothes in } \\
\text { the past were not very sus- } \\
\text { tainable" }\end{array}\end{array}$ & $\begin{array}{c}\text { Drawing a relationship be- } \\
\text { tween the event and prior } \\
\text { experiences or knowledge }\end{array}$ \\
\hline $\begin{array}{c}\text { "We rely on plastic but it has } \\
\text { so many issues, including pol- } \\
\text { lution and health } \\
\text { problems" }\end{array}$ & $\begin{array}{c}\text { Considering broader ethical, } \\
\text { social or political factors and } \\
\text { impacts }\end{array}$ & \\
\hline $\begin{array}{c}\text { "I think using science and art } \\
\text { together can really change } \\
\text { future technology" }\end{array}$ & $\begin{array}{c}\text { Developing a plan, hypothe- } \\
\text { sis, model or imagining future } \\
\text { actions or developments }\end{array}$ & Reasoning \\
"Tomorrow I will..." & & \\
\hline
\end{tabular}

FIGURE 2 | Reflection framework to evaluate reflection in zines, based on Ryan and Ryan 4Rs (2015) including levels of reflection and textual examples.

pedagogical, with neither the arts or the STEM discipline given precedence over the other. The learning design of all of these STEAM programmes promotes learner autonomy and agency through problem-solving, open-ended discovery, and exploration. Programmes are anchored around societal issues and challenges, with learners frequently asked to attend to the ethical, political or economic dimensions of a STEAM-related topic. There is also a focus on facilitation as a process which supports young people in their own construction of knowledge and meaning, rather than direct instruction. These features support the development of "learning as an activist project" Bevan et al. (2020b), (p. 3) in informal STEAM settings, empowering youth to be "critical thinkers and agentive individuals." Considering the historic use of zines for political action and engagement, they are a useful tool in such environments where learning is considered activist, thanks to their ability to support ownership of and meaningful engagement with STEAM knowledge.

\section{METHODS}

Zines were trialled as a reflective tool to support STEAM learning between November 2019 and February 2020 within the context of Science Gallery Dublin's OPEN MIND Studio, a week-long informal STEAM learning program for students aged 15-16 years old (Hurley, 2019). More than 130 young people were introduced to zine-making and supported to adopt the practice as a way to share their thoughts, feelings and experiences throughout their time at Science Gallery Dublin. Within this trial, zine-making occurred at the end of each of the five days and lasted between $40 \mathrm{~min}$ and $1 \mathrm{~h}$. Through an iterative approach based on learner and facilitator feedback, the zine-making sessions were refined and adjusted. The details of each stage are presented in more detail below, to provide guidance for practitioners wishing to adopt this methodology in their own settings.

\section{Step 1: Introducing Learners, to Zines and Zine Culture}

By introducing learners to zine history and culture, they are grounded in an understanding that zines are first and foremost about self-expression, identity work, and exploring ideas, and communities of knowledge. Sharing choice examples of relevant zines The Burgundy Zine, (2021); Wang, (2021) can help learners to see that this is an exercise for them to own, customise and play with, as many have done before them. This is a stark distinction to other forms of evaluation such as surveys, which seek answers to specific questions. Instead, zine-making is grounded in what learners themselves wish to contribute (their own creativity, reflection) and take away (their zine, participation in and appreciation of a larger zine community) from the process. 

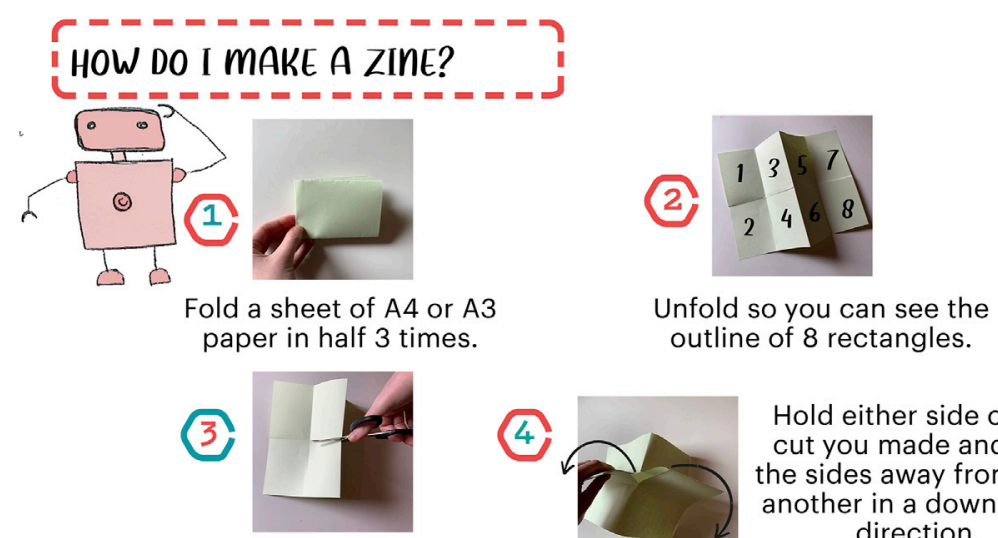

Cut down the midline of rectangles $3 \& 4$ and $5 \& 6$

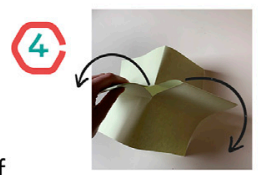

Hold either side of the cut you made and pull the sides away from oneanother in a downwards direction.

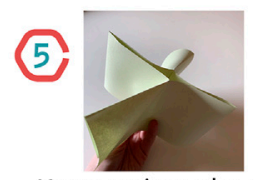

Keep going, the paper should make a cross shape.

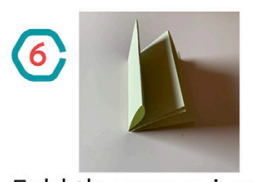

Fold the pages inwards to make a booklet.

FIGURE 3 | Folding instructions for creating a zine.

\section{Step 2: Folding the Zine}

There are a number of zine binding methods, but the authors suggest the simple folding method, demonstrated in Figure 3 below. This method involves making a "pocket zine" the result of folding a piece of A4 paper in half, three times.

\section{Step 3: Prompting Science, Technology, Engineering, Arts, and Mathematics PedagogyEpistemic Practices: Exploration, Meaning-Making, Critique and Reflection}

Though zines lend themselves to a combination of visual and textual communication, learners were made aware that they could choose one, the other, or both of these methods. Scaffolding the process of reflection with more structure was necessary in order to meaningfully support the learning experience. A series of prompts were refined, informed by the questions listed in Zines as a Science, Technology, Engineering, Arts, and Mathematics Pedagogy. The topic or concept can be replaced depending on the setting.

The prompts used to scaffold the zine reflections are as follows:

1. What do you wish people knew about [topic/concept explored during workshop]?

2. Is this topic related to anything you have learned in school or elsewhere? If so, how?

3. What are the impacts of [topic/concept]?

4. Did anything about this workshop surprise you? If so, what?

5. Make any final edits to your zine and prepare to share with the group

\section{Step 4: Developing a Reflective Environment.}

While introducing zines, folding them, and introducing the prompt questions go some way to developing a reflective atmosphere within the learning space, facilitators are advised to further this atmosphere by experimenting with the room layout, noise levels, and their own experience within their unique non-formal learning environment to explore what works most to support learner reflection. Learners were never advised not to speak, but often fell into quietude during the zine making sessions. Developing the appropriate atmosphere in the room will necessarily vary from group to group, and facilitators must be reflexive and respond to the groups' needs.

\section{Step 5-Sharing their zine}

Learners are invited to share their zines and to explain the motivations behind the topics they covered and the creative decisions they made. This encourages learners to clarify their visions and provides an opportunity for further reflection through dialogue (Knobel and Lankshear, 2002). This step is optional, but the community building potential of sharing zines and finding like-minded peers who share similar positionalities, values, and experiences has been a major benefit of the medium across the five testing locations.

\section{Step 6-Evaluate Outcomes}

Practitioners choosing to implement this zine method within an out-of-school learning environment may use the Ryan and Ryan (2015) 4Rs evaluation framework (Figure 2) to support their evaluation of the zines created. 


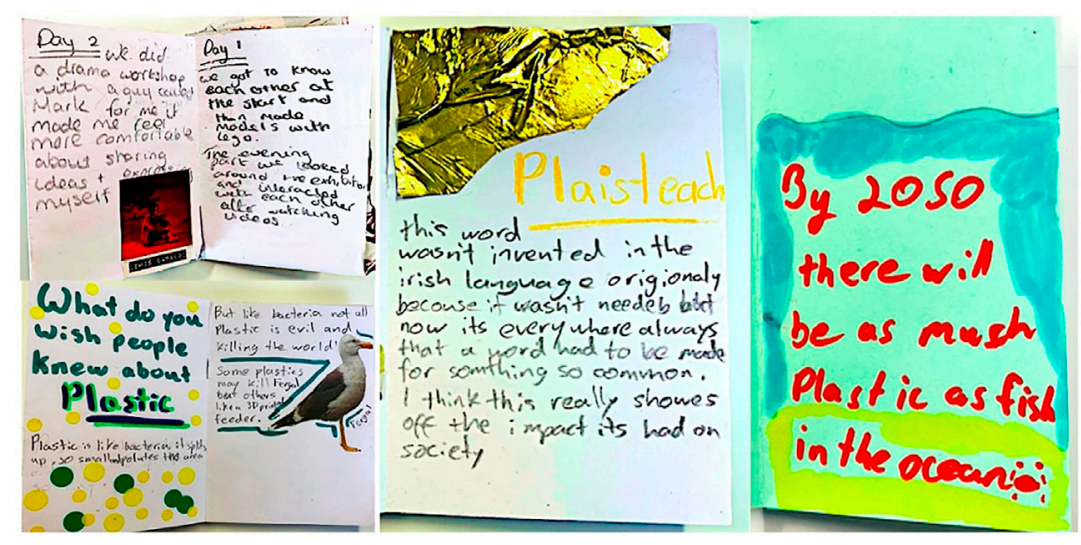

FIGURE 4 | A sample of zine pages created during STEAM workshops at Science Gallery Dublin.

Sample pages from zines created at Science Gallery Dublin can be seen in Figure 4. These zines were created during the initial development period of the tool and provided a kind of pedagogical and methodological blueprint to be followed by the institutions discussed in Learning Environments. These zines were created during a STEAM workshop series which covered topics related to conservation, sustainability, and the proliferation of plastic. Examples of each of the 4Rs shown in Figure 2 (reporting/responding, relating, reasoning, and reconstructing) are identified in the zines shown in Figure 4, and discussed briefly below.

Reporting/responding: In the sample image at the top left of Figure 4, a learner first reports on their experiences during the first day of the workshops stating, "We got to know each other at the start and then made models with Lego..." On day 2 the learner takes their reflection a step further sharing how the experience made them feel, "We did a drama workshop with a guy called Mark. For me, it made me feel more comfortable about sharing ideas + expressing myself." It is also interesting to note that the learner chose not to respond to the prompts but felt comfortable to take ownership of the medium to document what was most meaningful to them.

Relating: In the image on the bottom left of the figure, another learner chose to write one of the prompts into their zine and responded by drawing a comparison between their understanding of bacteria and plastic. The learner also created a kind of character based on an image cut from a magazine, "Fergal" a seagull. The learner goes on to state in written text that like bacteria "not all plastic is evil..." and provides a brief example of how the character might benefit from an item made of plastic.

Reasoning: In the center image beneath a triangle of gold leaf, a learner shares their reflections on plastic's impacts on the Irish language. While the workshops focused on the proliferation of plastic as a material and its impacts on health, wellbeing and the environment, this learner chose to reflect on how it had changed their language and further how this could be considered evidence for its broader impacts on society.

Reconstructing: In the sample image on the right in Figure 4, another learner describes a not-so-distant future in which plastic particles outnumber the fish in the ocean. The text is framed by blue waves and underscored by yellow sand both drawn in marker. This prediction or hypothesis builds on the environmental interventions and challenges explored during the workshops and provides another example of a learner which chose to go beyond the prompts to imagining a possible future.

\section{FACILITATOR FEEDBACK AND REFLECTIONS}

Having finalised the above method through trials at Science Gallery Dublin, facilitators and program managers from Ars Electronica, LATRA, Kersnikova and Waag put the process into practice in their own institutions. They then reflected on the experience, noting the ways in which learners and workshop organisers navigated the process. These reflections have helped to identify the strengths, weaknesses and recommendations associated with using this tool, which are shared below.

Participants in the sessions which lasted between 45 and 60 min reported the highest level of enjoyment during the zine making process.

Facilitators also noted that zines provided a chance for learners to find a personalised way of communicating complex thoughts and ideas through text or image or some combination of the two. They also provided more introverted students an opportunity to express and share their reactions to a learning experience. This creative freedom allowed for non-traditional explorations of material and opportunities for learners to connect with subject matter in novel ways, demonstrating multiple literacies and providing practitioners with a deeper understanding of the ways each participant was relating to the workshops. It also created unique opportunities for further dialogue between participants and facilitators exploring the multiplicity of meaning which emerged from the reflective practice.

Further feedback suggested that the zines presented a chance for learners to take more active ownership of the learning process in choosing which moments to document, critique, and respond 
to, within this material object that they had created. These are artifacts which by design, belong to the learner, not to the facilitator, institution, or researchers-situating the learner explicitly in a seat of creative power and knowledge-making. Many learners wished to keep their zines following the learning experience. In some instances, it was reported that in addition to providing a personal record and response to a learning opportunity, the completion of the zine-making process offered some learners a sense of achievement and closure to the experience.

As both a visual and text-based artifact, the zine as a reflective tool it is capable of capturing broad responses to learning experiences which blur disciplinary boundaries (Congdon and Blandy, 2005). By their nature, zines can be adapted to multiple learning environments and learner needs. Requiring only pen and paper as material resources, learners are able to document and reflect deeply on learning experiences in a small booklet of their own design. As an alternative form of media with roots in DIY culture, zines have evolved an amateurish aesthetic which places primacy on the personal experiences and interpretations of the zine creator. In the feedback shared from both learners and facilitators, this has worked to minimize anxieties around social and academic resources.

In some cases, the openness of the medium became a source of creative anxiety. Some learners at times felt frustration with the process, with one facilitator reporting that learners at their institution felt their drawings were "ugly", while others expressed feeling rushed while creating their zines. In some instances, learners expressed confusion over the lack of parameters inherent in the activity. In order to mitigate some of these frustrations and creative anxieties, some facilitators chose to use colored paper as opposed to white paper which resulted in a more relaxed attitude toward drawing and collage. Framing the prompts as provocations and inspiration for the zine-making process also served to address some challenges regarding the open-ended nature of the task. Some also played music during the sessions to support a more relaxed and reflective atmosphere. One of the most common challenges across all locations was the amount of time required for zine-making. Once learners became comfortable with the medium, many of them felt there was not ample time to fulfill their vision for their own zine.

\section{DISCUSSION AND CONCLUSION}

Zines allow a new kind of dialogue to take place between learners, educators, and institutions. Reflective zines encourage their makers to remix, re-present, and reimagine science and STEAM learnings in ways which position the maker as the knowledge creator and expert. Many of the organisations involved in the trial of this approach have chosen to continue to adapt and apply it in further programming, citing its enjoyable and empowering nature in giving voice to all learners especially those who are part of marginalized communities.
As outlined in the previous section, a lack of structure and parameters may be a barrier for some learners including those who are unfamiliar with reflective practice or zines. While the medium is meant to allow for creative freedom, some structure is needed to provide further support for reflective thinking. With the addition of the prompts, learners often provided reflections which reasoned through and reconstructed science and STEAM learning activities. The prompts provided learners with inspiration but allowed for enough personal freedom and choice to decide what they felt was most important to document.

The facilitators, researchers, and practitioners shared a number of key takeaways from their experiences utilising zines as reflective tools across informal STEAM learning settings:

1. Support learner creativity. Be clear that there is no right or wrong way to make a zine. This should be repeated throughout the zine sessions to mitigate creative anxieties and to instil that experience is about reflection and taking ownership of knowledge.

2. Remind the learners that this object belongs to them. Its value and purpose is entirely up to the learner.

3. Provide ample time. When learners are allowed to sink into the zine making process their reflections become more detailed and the experience is more enjoyable for them.

4. Create a reflective atmosphere. Playing music, even letting the learners choose the music can be an effective way of creating a relaxed space

5. Be flexible. Some learners will need more exposition while others will dive right in. Having examples of zines on hand is a helpful way to alleviate any uncertainties caused by the openness of the medium.

Reflective approaches for cultural institutions are more important than ever given the COVID-19 pandemic, racial reckoning, and continued global political and economic uncertainty, meaning that now is "the moment to act with humility and courage, to reform our approaches, and become cultural institutions which welcome, support, and value all communities" (Brown et al., 2020). Zines offer an inclusive and emancipatory opening to inter-and transdisciplinary thinking and the testing of ideas. They can act as a model or path into public participation on any number of subjects. It is a DIY medium where creators are able to dissect and reconfigure topics of interest and experiment with new ideas, hypotheses, and information (Congdon and Blandy, 2003). Zines encourage learners to relate their personal experiences, identities and values to STEAM subjects and to explore fresh connections to similar topics touched upon in more formal learning environments and in their day to day lives.

\section{DATA AVAILABILITY STATEMENT}

The raw data supporting the conclusion of this article will be made available by the authors, without undue reservation. 


\section{ETHICS STATEMENT}

The studies involving human participants were reviewed and approved by the Trinity College Dublin research ethics committee. Written informed consent to participate in this study was provided by the participants' legal guardian/next of kin.

\section{AUTHOR CONTRIBUTIONS}

$\mathrm{AB}$ led the conceptual design of this manuscript. $\mathrm{AB}, \mathrm{SP}, \mathrm{MH}$, and JR wrote the initial drafts collaboratively. AB and SP co-led the research intervention in the field while $\mathrm{MH}$ designed and coordinated the research project within which this work was realised. All authors reviewed the manuscript and provided comments and feedback.

\section{REFERENCES}

Archer, L., Godec, S., Calabrese Barton, A., Dawson, E., Mau, A., and Patel, U. (2021). Changing the Field: A Bourdieusian Analysis of Educational Practices that Support Equitable Outcomes Among Minoritized Youth on Two Informal Science Learning Programs. Sci. Edu. 105 (1), 166-203. doi:10.1002/sce.21602

Bartel, J. (2004). From A to Zine: Building a Winning Zine Collection in Your Library. Chicago, IL: American LIbrary Association.

Bell, P., Lewenstein, B., Shouse, A., and Feder, M. (2009). Learning Science in Informal Environments: People, Places and Pursuits. Washington, DC: National Academies Press.

Bevan, B., Mejias, S., Rosin, M., and Wong, J. (2020a). The Main Course Was Mealworms: The Epistemics of Art and Science in Public Engagement. Leonardo 1 (1), 1-14. doi:10.1162/leon_a_01835

Bevan, B., Peppler, K., Rosin, M., Scarff, L., Soep, E., and Wong, J. (2019). "Purposeful Pursuits: Leveraging the Epistemic Practices of the Arts and Sciences," in Converting STEM into STEAM Programs: Methods and Examples from and for Education. Editors A. J. Stewart, M. Mueller, and D. J. Tippins (Gewerbestr: Springer), 21-38. doi:10.1007/978-3-030-25101-7_3

Bevan, B., Ryoo, J. J., Vanderwerff, A., Wilkinson, K., and Petrich, M. (2020b). "I See Students Differently": Following the Lead of Maker Educators in Defining what Counts as Learning. Front. Edu. 5 (121), 1-10. doi:10.3389/feduc.2020. 00121

Bleyer, J. (2004). "Cut-and-paste Revolution: Notes from the Girl Zine Explosion," in The Fire This Time: Young Activists and the New Feminism. Editors V. Labaton and D. L. Martin (New York, NY: Anchor Books), 42-60.

Bretnor, R. (1974). Science Fiction, Today and Tomorrow. Evanston, New York: Harper \& Row.

Brown, A., Roche, J., and Hurley, M. (2020). Engaging Migrant and Refugee Communities in Non-formal Science Learning Spaces. Jcom 19 (4), R01. doi:10. 22323/2.19040601

M. Braud and M. J Reiss (Editors) (2004). Learning Science outside the Classroom. London: Psychology Press.

Calabrese Barton, A., and Tan, E. (2018). A Longitudinal Study of Equity-Oriented STEM-Rich Making Among Youth from Historically Marginalized Communities. Am. Educ. Res. J. 55 (4), 761-800. doi:10.3102/ 0002831218758668

Carlile, O., and Jordan, A. (2007). "Reflective Writing: Principles and Practice," in Teaching Portfolio Practice in Ireland: A Handbook. Editor C. O'Farrell and D. Soskice, 24-37.

Chidgey, R. (2009). Free, Trade: Distribution Economies in Feminist Zine Networks. Signs: J. Women Cult. Soc. 35 (1), 28-37. doi:10.1086/599265

Cohn, M. (2004). User Stories Applied: For Agile Software Development. Boston: Addison-Wesley Professional, 260-268.

\section{FUNDING}

This work was made possible with funding from the European Union's Horizon 2020 Research and Innovation Program under Grant Agreement No. 788317.

\section{ACKNOWLEDGMENTS}

The authors are grateful for the support of SySTEM 2020 consortium. The authors are also grateful to the workshop participants and facilitators across our research partners. Muiriosa Guinan and Joanna Crispell from Science Gallery Dublin research and learning team were also key in developing the zine as a reflective tool.

Congdon, K. G., and Blandy, D. (2003). Zinesters in the Classroom: Using Zines to Teach about Postmodernism and the Communication of Ideas. Art Edu. 56 (3), 44-52. doi:10.1080/00043125.2003.11653501

Congdon, K. G., and Blandy, D. (2005). Zines, DIY, and Critical Pedagogy. Telemedia: J. Media Literacy 52 (1-2), 59-63.

Costantino, T. (2018). STEAM by Another Name: Transdisciplinary Practice in Art and Design Education. Arts Edu. Pol. Rev. 119 (2), 100-106. doi:10.1080/ 10632913.2017.1292973

Dawson, E. (2018). Reimagining Publics and (Non) Participation: Exploring Exclusion from Science Communication through the Experiences of Low-Income, Minority Ethnic Groups. Public Underst Sci. 27 (7), 772-786. doi:10.1177/0963662517750072

DeGravelles, K. (2011). In the Ruins of Zine Pedagogy: A Narrative Study of Teaching With Zines. Doctoral Dissertation. Louisiana State University.

Desyllas, M. C., and Sinclair, A. (2014). Zine-Making as a Pedagogical Tool for Transformative Learning in Social Work Education. Soc. Work Edu. 33 (3), 296-316. doi:10.1080/02615479.2013.805194

Dewey, J. (1933). How We Think. Buffalo, NY: Prometheus Books.

Di Stefano, G., Gino, F., Pisano, G., and Staats, B. (2011). Making Experience Count: The Role of Reflection in Individual Learning. Working Paper No. 14093. Boston: Harvard Business School.

Dierking, L. (2005). Lessons Without Limit: How Free-Choice Learning is Transforming Science and Technology Education. Hist. Cienc. Saude Manguinhos 12 (Suppl.), 145-160.

Duncombe, S. (1997). Notes from Underground: Zines and the Politics of Alternative Culture. Portland, Oregon: Microcosm Publishing.

Dunlop, L., Clarke, L., and McKelvey-Martin, V. (2019). Free-choice Learning in School Science: A Model for Collaboration between Formal and Informal Science Educators. Int. J. Sci. Educ. B. 9 (1), 13-28. doi:10.1080/21548455.2018. 1534023

Dunwoody, S. (1992). The challenge for Scholars of Popularized Science Communication: Explaining Ourselves. Public Underst Sci. 1 (1), 11-14. doi:10.1088/0963-6625/1/1/002

Durall, E., Bauters, M., Hietala, I., Leinonen, T., and Kapros, E. (2020). Co-creation and Co-design in Technology-Enhanced Learning: Innovating Science Learning outside the Classroom. Interaction Des. Architectures 42 (1), 202-226.

Falk, J. H. (2005). Free-Choice Environmental Learning: Framing the Discussion. Environ. Educ. Res. 11, 265-280.

Falk, J. H., and Dierking, L. D. (2000). Learning from Museums: Visitor Experiences and the Making of Meaning. Walnut Creek: AltaMira Press.

Garibay, C., and Teasdale, R. M. (2019). Equity and Evaluation in Informal STEM Education. Evaluation 2019 (161), 87-106. doi:10.1002/ev.20352

Garrison, E. K. (2000). U.S. Feminism-Grrrl Style! Youth (Sub)Cultures and the Technologics of the Third Wave. Feminist Stud. 26 (1), 141-170. doi:10.2307/ 3178596 
Gondwe, M., and Longnecker, N. (2015). Scientific and Cultural Knowledge in Intercultural Science Education: Student Perceptions of Common Ground. Res. Sci. Educ. 45 (1), 117-147. doi:10.1007/s11165-014-9416-Z

Guzzetti, B. J., and Gamboa, M. (2004). Zines for Social justice: Adolescent Girls Writing on Their Own. Reading Res. Q. 39 (4), 408-436. doi:10.1598/rrq.39.4.4

Guzzetti, B. J. (2009). “Adolescents Explorations With Do-It-Yourself Media: Authoring Identity in Out-of-School Settings," in New Literacies Practices: Designing Literacy Learning. Editor M. J. Hagood (New York, NY: Peter Lang), 41-57.

Hall, C. (2020). TAKING NOTE: Annotated Portfolio as a Method to Analyse the Experience of Design Research Practice. J. Textile Des. Res. Pract. 8 (2), 209-231. doi:10.1080/20511787.2020.1751960

Honma, T. (2016). From Archives to Action: Zines, Participatory Culture, and Community Engagement in Asian America. Radic. Teach. 105, 35-36. doi:10. 5195/rt.2016.277

Hurley, M. (2019). "Praktijkvoorbeeld 1. Science Gallery Dublin," in Cultuur+Educatie: Arts Sciences. Editors M. Bremmer and E. Heijnen, Amsterdam), Vol. 18, 34-35. doi:10.1097/01.nt.0000579416.63513.25

Johnson, A. A. A., and Johnson, R. M. (1974). Forgotten Pages: Black Literary Magazines in the 1920s. J. Am. Stud. 8 (3), 363-382. doi:10.1017/ S0021875800015930

Knobel, M., and Lankshear, C. (2002). "Cut, Paste and Publish: The Production and Consumption of Zines," in Adolescents and Literacies in a Digital World. Editor D. E. Alvermann, 164-185. New York: Peter Lang Publishing.

Lee, C., and Soep, E. (2018). Beyond Coding: Using Critical Computational Literacy To Transform Tech. Tex. Edu. Rev. 6, 10-16. doi:10.15781/T24J0BF37

Liao, C. (2016). From Interdisciplinary to Transdisciplinary: An Arts-Integrated Approach to STEAM Education. Art Edu. 69 (6), 44-49. doi:10.1080/00043125. 2016.1224873

Liu, C. (2019). Circuit Bending, self-published zine.

Lonsdale, C. (2015). Engaging the "Othered:" Using Zines to Support Student Identities. Lang. Arts J. Mich. 30 (2), 8-16. doi:10.9707/2168$149 x .2066$

Löwgren, J. (2013). Annotated Portfolios and Other Forms of Intermediate-Level Knowledge. Interactions 20 (1), 30-34. doi:10.1145/2405716.2405725

Matuk, C., Gerard, L., Lim-Breitbart, J., and Linn, M. (2016). Gathering Requirements for Teacher Tools: Strategies for Empowering Teachers through Co-design. J. Sci. Teach. Edu. 27, 79-110. doi:10.1007/s10972-0169459-2

Mejias, S., Thompson, N., Sedas, R. M., Rosin, M., Soep, E., Peppler, K., et al. (2021). The Trouble with STEAM and Why We Use it Anyway. Sci. Edu. 105 (2), 209-231. doi:10.1002/sce.21605

Moore, S., Roche, J., Bell, L., and Neenan, E. E. (2020). Supporting Facilitators of Maker Activities through Reflective Practice. J. Mus. Edu. 45 (1), 99-107. doi:10. 1080/10598650.2019.1710688

Nazar, C. R., Barton, A. C., Morris, C., and Tan, E. (2019). Critically Engaging Engineering in Place by Localizing Counternarratives in Engineering Design. Sci. Ed. 103 (3), 638-664. doi:10.1002/sce.21500

Orthia, L. (2020). Strategies for Including Communication of Non-western and Indigenous Knowledges in Science Communication Histories. J. Sci. Commun. 19 (2). doi: $10.22323 / 2.19020202$

Poletti, A. (2005). Self-publishing in the Global and Local: Situating Life Writing in Zines. Biography 28, 183-192. doi:10.1353/bio.2005.0035

Polk, E., and Diver, S. (2020). Situating the Scientist: Creating Inclusive Science Communication through Equity Framing and Environmental justice. Front. Commun. 5 (6), 1-10. doi:10.3389/fcomm.2020.00006

Radway, J. (2001). "Girls, Zines, and the Miscellaneous Production of Subjectivity in an Age of Unceasing Circulation," in Speaker Series. Editors L. BridwellBowles and M. Akdere (Minneapolis: University of Minnesota: A Lecture
Presented by the Center for Interdisciplinary Studies of Writing and the Literacy \& Rhetorical Studies Minor), 18.

Radway, J. (2011). Zines, Half-Lives, and Afterlives: On the Temporalities of Social and Political Change. Publ. Mod. Lang. Assoc. Am., 126. 140-150. doi:10.1632/ pmla.2011.126.1.140

Rallin, A., and Barnard, I. (2008). The Politics of Persuasion versus the Construction of Alternative Communities: Zines in the Writing Classroom. Reflections 7 (3), 46-57.

Roche, J., Bell, L., Galvão, C., Golumbic, Y. N., Kloetzer, L., Knoben, N., et al. (2020). Citizen Science, Education, and Learning: Challenges and Opportunities. Front. Sociol. 5 (613814), 1-10. doi:10.3389/fsoc.2020. 613814

Ryan, M., and Ryan, M. (2015). “A Model for Reflection in the Pedagogic Field of Higher Education," in Teaching Reflective Learning in Higher Education. Editor M. E. Ryan (Cham: Springer), 15-27. doi:10.1007/978-3-31909271-3_2

Sangrá, A., Raffaghelli, J. E., and Guitert-Catasús, M. (2019). Learning Ecologies through a Lens: Ontological, Methodological and Applicative Issues. A Systematic Review of the Literature. Br. J. Educ. Technol. 50 (4), 1619-1638. doi:10.1111/bjet.12795

ScienceGrrl (2018). Available at: https://sciencegrrl.co.uk (Accessed Januray 10, 2021).

Souto-Manning, M. (2006). A Critical Look at Bilingualism Discourse in Public Schools: Autoethnographic Reflections of a Vulnerable Observer. Biling. Res. J. 30 (2), 559-577. doi:10.1080/15235882.2006.10162890

The Burgundy Zine (2021). Welcome to the Burgundy Zine. Available at: https:// burgundyzine.com/.

Tutkal, S., Busnelli, V., Castelao-Huerta, I., Barbosa dos Santos, F., Loaiza Orozco, L. F., and Rivera Arcila, D. (2021). Inhabiting Borders: Autoethnographic Reflections of PhD Students in Colombia. Teach. Higher Edu. 26 (3), 321-339. doi:10.1080/13562517.2021.1895108

Tzou, C., Suárez, E. P., LaBonte, D., Starks, E., Bang, M., et al. (2019). Storywork in STEM-Art: Making, Materiality and Robotics within Everyday Acts of Indigenous Presence and Resurgence. Cogn. Instruction 37 (3), 306-326. doi:10.1080/07370008.2019.1624547

Vong, S. (2016). REPORTING OR RECONSTRUCTING? the Zine as a Medium for Reflecting on Research Experiences. Commun. Inf. Literacy 10 (1), 3. doi:10. 15760/comminfolit.2016.10.1.15

Wang, S. (2021). Science Under The Scope: Putting Science In Perspective. Available at: https://freerads.org/science-scope-full/.

Williamson, J. (1994). "Engaging Resistant Writers through Zines in the Classroom," in Paper presented at the College Composition and Communication Annual Convention, March 1994, Nashville, TN. Available at: http://wac.colostate.edu/rhetnet/judyw_zines.html (Accessed Januray 15, 2021).

Yang, A. (2010). Engaging Participatory Literacy through Science Zines. Am. Biol. Teach. 72 (9), 573-577. doi:10.1525/abt.2010.72.9.10

Conflict of Interest: The authors declare that the research was conducted in the absence of any commercial or financial relationships that could be construed as a potential conflict of interest.

Copyright (C) 2021 Brown, Hurley, Perry and Roche. This is an open-access article distributed under the terms of the Creative Commons Attribution License (CC BY). The use, distribution or reproduction in other forums is permitted, provided the original author(s) and the copyright owner(s) are credited and that the original publication in this journal is cited, in accordance with accepted academic practice. No use, distribution or reproduction is permitted which does not comply with these terms. 